\title{
Berrikuntza Haur Hezkuntzako kanpo espazioan: diseinuaren kalitatea eta haurraren jolasa
}

\author{
Marta Artola Bardeci \\ Iñaki Larrea Hermida \\ Alexander Barandiaran Arteaga \\ Humanitate eta Hezkuntza Zientzien fakultatea \\ Mondragon Unibertsitatea
}

DOI: $10.1387 / \operatorname{tantak.17868}$

GAKO-HITZAK: Haur hezkuntza, berrikuntza pedagogikoa, kanpo espazioa, jolasa, hezkuntza kalitatea.

\section{SARRERA}

Haur Hezkuntzako kanpo espazioak oso garrantzitsuak dira haurraren garapenerako (Fjortoft, 2004). Haurraren jolasean, ikaskuntzan zein garapenean izan dezaketen eraginagatik, kanpo espazioa goi mailako baliabide pedagogikotzat hartzea aldarrikatzen dute Moserek eta Martinsenek (2010). Horregatik, beren diseinua zaindu beharrekoa da (Miranda, Larrea eta Muela, 2014). Hala ere, Haur Hezkuntzako egunerokotasunean garrantzi eskasa ematen zaio kanpo espazioari. Ikerketei dagokienez ere, gure testuinguruan gaiak ez du ikertzaile askoren arreta piztu, Haur Hezkuntzan egin diren ikerketa gehienek gela barruko dinamika aztertu baitute (Miranda et al., 2014).

Eskolako testuingurura mugatu gabe, gaur egungo gizarteak inoiz baino gehiago aldentzen ditu haurrak kanpo espazioetatik. Hainbat arrazoi daude hori horrela izateko, hala nola, teknologiak, trafikoa, eguraldia eta hezkuntza erakundeak (Doucette, Kowalski eta Ransom, 2007; Ernst 2014; Fdzila eta Said; 2010; Maynard eta Waters, 2007). Teknologiari dagokionez, haurrak gero eta lehenago hasten dira horiek erabiltzen, eta sasoi batean kanpoan ematen zuten denbora nolabait ordezkatu egin dute (Doucette et al., 2007). Trafikoaren handitzea, berriz, arrisku faktoretzat hartu da eta horrekin batera kanpo espazioaren erabilerarako muga bihurtu da. Hainbat testuingurutan, ordea, Galeseko eskola batzuetan kasu (Maynard eta Waters, 
2007), eguraldi euritsu edo hotza kanpo espazioa ez erabiltzeko arrazoia da. Are gehiago, heldu askok kanpo espazioaren balioa gutxietsi egiten dute, bertan haurrak aztoratzen direlakoan. eta, ondorioz, bere erabilera mugatzen diete haurrei (Burris eta Burris, 2011). Ideia horrekin bat, Mirandak, Larreak eta Muelak (2014) zehazten dute haurrek normalean 30 minutu inguru besterik ez dutela ematen kanpo espazioan eskolan daudela. Beraz, mugatutako denbora da (Burris eta Burris, 2011; Maynard eta Waters, 2007; Miranda, Larrea, Muela, Martínez de Lagos eta Barandiaran, 2015).

Erabilera mugatuaren atzean egon daiteke irakasle asko ez jabetzea kanpo espazioaren onurez eta erabilerez (Maynard eta Waters, 2007). Irakasle askok uste dute kanpo-espazioa erabili behar dela ikasleek korrika egiteko, eta horrela nekatzeko edo lasaitzeko. Horregatik, kanpo espazioaren inguruan sakonago hausnartzea aldarrikatu da (Miranda et al., 2014) eta, bidenabar, beharrezkotzat hartu da kanpo espazioaren onuretan arreta jartzea (Fdzila eta Said, 2010).

\section{KANPO ERABILERAK HAURRAREN ONGIZATEAN DITUEN ONURAK}

Ikertzaile askok interesa izan dute kanpo espazioak erabiltzearen onurak aztertzean. Adibidez, kanpo espazioetan jolasten diren haurrek beren jarrera eta oreka eta koordinazioa bezalako trebetasunak hobetzen dituzte, eta osasun hobea dute, gizentasuna gutxitu eta sistema inmunologikoa hobetzen delako (Fjortoft, 2001, 2004). Horrez gain, kanpo espazioetan aritzea lagungarria da haurren arazoak edo gatazkak konpontzeko trebetasunerako, haurren sormenerako eta arreta gaitasunerako (Fdzila eta Said, 2010; Mårtensson, Boldemann, Söderström, Blennow, Englund eta Grahn, 2009).

Era berean, kanpo espazioan irudimen aktiboa garatzeko aukera dute (Canning, 2010). Halaber, toki aproposa da esplorazioa, aurkikuntza, jakin-mina eta umeen parte-hartzea bultzatzeko eta haurren garapen integralerako (Fdzila eta Said 2010). Oro har, baieztatu izan da haurrak kanpo espazioan egoteak zein jolasteak eragin positiboa duela. Azken batean, behin baino gehiagotan aztertu da kanpo espazioaren eta haurraren garapenaren dimentsio ezberdinen arteko erlazioa (Fdzila eta Said 2010; Fjortoft 2001, 2004; Moser eta Martinsen 2010).

Garapen motoreari dagokionez, kanpo espazioak baimentzen du orekaren eta giharren lanketa, bertan aukera egon ohi delako oztopoen gainetik salto egiteko, materialak jasotzeko eta botatzeko eta ontziak edo beste material batzuk betetzeko (Early Head Start National Resource Center, 2013; Fjortoft 2004, 2001; Gray, et al., 2015).

Garapen kognitiboari erreparatuta, kanpo espazioak ahalbidetzen du naturarekin harreman zuzena izatea, eta horrek esperientzia aberatsak eskaintzen dizkio haurrari naturarekin lotutako kontzeptuak ulertzeko eta 
errespetatzeko. Ildo beretik, kanpo espazioa lagungarria izan daiteke ikasgeletan ikasitakoarekin lotura edo erlazioak egiteko eta kausa-eraginak errazago ulertzeko. Azkenik, kanpo espazioan ematen den esperimentazioak, oharkabean susta dezake bolumena, pisua eta beste kontzeptu matematiko batzuen ulermena (Early Head Start National Resource Center, 2013; Fjortoft 2001, 2004; Gray et al., 2015).

Arlo sozio-emozionalari dagokionez, aztertu da kanpo espazioaren eta haur txikien elkarrekiko errespetuaren arteko erlazioa. Naturarekin esperientziak partekatzen dituztenean, harreman estuagoak sortzen dituzte beraien artean zein helduekin, espazio honek eskaintzen baitu hainbat elkarrekintza izateko aukera (Early Head Start National Resource Center, 2013; Fjortoft, 2001, 2004).

Azkenik, kanpo espazioan hizkuntza garatzeko aukerak ere zabaltzen dira, beste haurrekin elkarrekintzak izaten dituztenean edo naturarekiko harremana izaten dutenean, haurrek hiztegi berria jaso eta jariakortasuna hobetzeko aukera baitute normalean bere interesekoak diren gaien inguruan (Early Head Start National Resource Center, 2013; Fjortoft 2001, 2004). Horrenbestez, kanpo espazioak garrantzitsuak dira jolaserako, ikasketarako eta garapenerako, eta, ondorioz, baliabide pedagogikotzat hartu behar dira (Moser eta Martinsen, 2010). Edozein kasutan, kanpo espazioaren potentzialtasuna benetan gauzatzeko, garrantzitsua da bere kalitatea (Miranda et al., 2014). Azken batean, ikastetxeak egiten duen eskaintzaren arabera, haurren garapen integrala bultzatu edo oztopatu dezake (Bar-Haim eta Bart, 2006).

\section{KANPO ESPAZIOAREN KALITATEA: DISEINUA ETA IRAKASLEAREN ROLA}

Hainbat autorek aldarrikatu zuten kanpo espazioen kalitatearen eta bertan egiten den eskaintzaren inguruan hausnartzeko beharra (Miranda et al., 2014). Egiten den eskaintzaren arabera, diseinuaren kalitatea handiagoa edo baxuagoa izan daiteke, eta horrek eragina izan dezake haurrarengan (Debord, Hestenes, Moore, Cosco eta McGinnis, 2005; Kos eta Jerman 2013). Kalitatearekin lotu izan dira kanpo espazioaren diseinua eta irakaslearen rola (Davies, 1997). Horregatik, jarraian, kanpo espazioaren diseinua eta irakaslearen rola izango dira hizpide.

\subsection{Kanpo espazioaren diseinua}

Programaren diseinuari dagokionez, hainbat autorek aipatzen dute espazioak hezkuntza komunitatearekin diseinatu beharko liratekeela kalitatezkoak izateko, hau da, haurren nahiak usteak, interesak kontuan hartu 
behar direla diseinua sortzerakoan (Conde eta Pinzolas, 2005; Gordillo, 2012; Miranda et al., 2015).Gainera, ulertu behar da interes horiek urtetik urtera aldatzen direla, haurrak mailatik aldatzen direlako (Conde eta Pinzolas, 2005; Gordillo, 2012). Horregatik, proposatzen dute urte bakoitzean aldaketa txikiak egitea besteen interesak kontuan hartzeko eta espazioaren kalitate altua mantentzeko. Beraz, irakasleak bermatu behar du urtetik urtera interes horiek eta kanpo espazioaren eskaintzak bat datozela. Horrez gain, kanpo espazioaren erabilera sistematikoa aldarrikatzen da, haurrei egun guztietan urte guztian zehar kanpoan jolasten utziz kanpo espazioa baliatu ahal izateko (Olse, 2013).

Kanpo espazioaren kalitateari dagokionez, jolasteko, hainbat elkarrekintza izateko, esploratzeko edota ikasteko eskaintza egokia egiten duen inguru naturalari deritzo (Kos eta Jerman, 2013; Luchs eta Fikus, 2013). Kalitate altu hori ziurtatzeko edo bermatzeko, hainbat eremu kontuan hartu behar dira.

Lehenik eta behin, ezinbestekoa da giro erosoa sortzea haurrak bertan ari direnean; hori dela eta, espazioek atseginak eta zainduak izan behar dute; eskuragarritasuna bermatu behar dute; eta jolasteko inguru egokiak izan behar dituzte (Debord et al., 2005).

Horretarako, Karinek eta Wrightek (2014) aipatzen dutenez, beharrezkoa da material aproposa, haurraren adinera eta ezaugarrietara egokitutako materiala alegia. Material horrek haurrei jolasteko hainbat aukera eskaini behar die, esate baterako, gauzak lurrera botatzeko, ikertzeko, esperimentatzeko, esploratzeko edo antolatzeko. Horren arrazoia da horrelako materialak kanpo espazioaren jolasa osotasunean garatzen duela. Horregatik, Karinen eta Wrighten (2014) eta Parsonsen (2011) arabera, eskaini behar dira estruktura gabeko materialak (makilak, harea, harriak), eraikuntzak sortzekoak (askatasunez nahi dutena sortzeko aukera eskaintzen dutenak), esploratzeko material naturala (harriak, harea, lurra, fauna), manipulatzeko materialak (testura ezberdineko tokiak, hainbat kolore besteak beste) eta sortuta dauden materialak (kulunkak, txirrista).

Kalitatezko eskaintzaren definizioaren harira, Fdzilak eta Saidek (2010) aipatu zuten kanpo espazioek ere ikuseremu ezberdinak eskaini behar dituztela haurrak toki batetik bestera mugitzeko eta ezkutatzera jolasteko. Beraz, eskaintzen diren espazioak ere horrelakoak izatea garrantzitsua izango litzateke, eskaintza honekin haurrek emozioa eta erronka esperimentatzen baitituzte (Fdzila eta Said, 2010).

Halaber, kalitate altuko kanpo espazioetan arriskuaren eta erronken sentsazioa sortu behar da toki aspergarriak ez bihurtzeko eta haurren potentzialtasuna garatzeko, beraien ikaskuntza esanguratsuagoa izateko eta hainbat esperientzia eta abentura sortzeko (Karin eta Wright, 2014; Larrea eta Barandiaran, 2012; Parsons, 2011). Adibidez, material naturalen bitartez, zehazki enbor edo harri ezberdinak erabilita, bide baten modukoak sor daitezke haurrak arrisku eta erronka sentsazioa izan dezan. 
Horrenbestez, kalitatezko kanpo espazio batek haurrei eskaini behar die jolas mota ezberdinetan parte hartzeko aukera, eta, horretarako, beharrezkoa da eskaintza zabala egitea (Mera, 2013; Moser eta Martinsen, 2010; Olse, 2013; Parsons, 2011; Perez, 2012). Jolas eskaintza hori anitza izan behar da haurraren garapen integrala bermatzeko (Frost, Wortham eta Reifel, 2005; Olse, 2013; Rubin, Fein eta Vandenberg, 1983). Azken batean, jolasa da haurraren garapen integralerako beharrezko elementua (Frost, Wortham, eta Reifel, 2005; Rubin et al., 1983).

Horregatik, Haur Hezkuntzan egiten den eskaintzan jolas mota batzuk kontuan hartu behar dira, horiek garrantzitsuak baitira aipatutako garapena bermatzeko (Ardanaz, 2009). Oso bestelako sailkapenak egin daitezkeen arren, jolas horiek dimentsio kognitiboaren eta sozialaren arabera sailka daitezke (Parten, 1932; Piaget, 1962; Smilansky, 1968). Jolas kognitiboari dagokionez, Piagetek (1962) ezagutza jasotzeko sistema psikologikotzat hartzen du. Garnerrek (2008) gaineratzen du ezagutza hori lotuta dagoela norbanakoaren esperientziekin, harremanekin eta arauekin. Sailkapenera itzuliz gero, dimentsio kognitiboaren arabera lau jolas mota zehaztu zituen Piagetek (1962): jolas funtzionala, eraikuntza jolasa, jolas sinbolikoa eta araututakoa.

Jolas funtzionalari dagokionez, behin eta berriro akzio bat pertsona batekin, objektu batekin edota gorputzarekin errepikatzean oinarritzen da. Era honetako jolasa jaiotzetik bi urtera bitartean nagusi da (Reina, 2009). Zentzumenen garrantzia aitorturik (Ardanaz, 2009), jolas funtzionalak garapenean ekarpen handia egiten dio haurrari, garapen motorean besteak beste.

Jolas kognitiboen sailkapenaren barruan, eraikuntza jolasa dago. haurrak lehenengo urtean hasten dira jolas mota hau garatzen eta pixkanaka urtetik urtera aldatzen doa. Hasiera batean bakarka jolastetik, besteekin eraikuntza jolasa egiterako eboluzioa dago. Garapenari ekarpen esanguratsua egiten dio, esaterako haurren sormenean, motrizitate finean, arretan, begi-esku koordinazioan edo memorian (Ardanaz, 2009; Reina, 2009).

Sailkapenarekin jarraituz, jolas sinbolikoa eta dramatikoa daude, haurrek bi urtetik zazpi urtera bitartean garatutako jolasak. Bertan, rol aldaketak eta fantasia izaten dira; gainera, jolas mota hau haurraren garapen kognitibo zein afektiboaren oinarria da. Bereziki hiru urtetik gorako haurrengan ikus daiteke, eta horren bitartez, haurrek sormena zein hizkuntza garatzen dute, errealitatea ulertzen dute eta ezagutza berriak ere garatzen dituzte. Jolas sinbolikoa bultzatzeko eskaintzari dagokionez, gehiegi egituratu gabeko materialak hobesten dira (Ardanaz, 2009; Reina, 2009). Azkenik, dimentsio kognitiboaren araberako sailkapenean, araututako jokoak daude. Arauak dituzten heinean, jolastzat hartzeko zalantzak daude.

Bestalde, dimentsio sozialaren haritik, kontuan izan behar da kanpo espazioak sortzen duela haurrak elkarrekin jolasteko aukera, eta modu horretan, jolas sozialerako abagunea eskaintzen da (Coplan, Rubin eta Findlay, 2006). Jolasa sozialtzat hartzeko beharrezkoa da hainbat subjektu batera 
jolastea (Coplan et al., 2006). Jolas soziala emateko haurrak motibatuta egon behar du beste haurrekin jolasteko eta jolas hori partekatzeko (Coplan et al., 2006).

Jolas sozialaren garapenari dagokionez, haurraren lehenengo bi urteetan, normalean jolas funtzionala nagusi duen sasoian, haurra ez da inorekin jolasten, beste bere gorputzarekin jolasten da beste haur batzuk behatzen egoten baita (Coplan et al., 2006). Bi urterekin jolas paraleloa garatzen du (Ardanaz, 2009). Jolas paraleloan haurra beste haur batzuen alboan jolasten da, sarri objektu berberekin, baina beren arteko elkarrekintzarik gabe (Ardanaz, 2009). Hiru eta bost urte bitartean, ordea, talde jolasa garatzen dute. Haurrek jolasa partekatzen dute eta elkarri hitz egiten diote, nolabait, jolasa beraien arteko elkarrekintzan oinarrituta (Rubin et al., 1983).

Dimentsio kognitiboaz eta sozialaz gain, autore batzuek zentzumenaren araberako sailkapena egiten dute (Escriba, 1998; 2002). Jolas sentsorialen sailkapen honek bost eremutan banatzen du jolasa, gehien eragindako zentzumenaren arabera: bisuala, ukimena, usaimena, dastamena eta entzumena. Sailkapen horretatik, iradokitzen da zentzumen ezberdinei begirako eskaintza egon beharko litzatekeela kanpo espazioan (Escriba, 1998), musika egiteko materiala kasu (Karin eta Wright, 2014; Olse, 2013).

Kanpo espazioaren eskaintzarekin jarraituz, jolas mota guztiak bere baitan har ditzaketen espazio zabalak aldarrikatu dira (Barandiaran, Larrea eta Lopez de Arana, 2011; Moser eta Martinsen, 2010). Are gehiago, Parsonsek (2011) gaineratzen du komeni dela hainbat gunetan antolatuta egotea: eskalatzeko area, estruktura gabeko materialen tokia, eraikuntzen area, naturaren lekua, ikusmenaren area, zentzumen area, musika eta mugimenduaren area, eta azkenik, asanbladako tokia. Azken horri dagokionez, gela barruan egin ohi diren hainbat jarduera ere kanpoan egin daitezke, esate baterako, asanbladak (Parsons, 2011).

Beraz, argi dago kanpo espazioek, material egokia eta jolasteko hainbat aukera eskaini behar dutela. Espazio seguruak izan behar dira, baina aldi berean, haurrari erronken zein arriskuaren sentsazioa izateko aukera eskaini behar dio, bere gaitasunak garatzeko eta bere garapen integrala bermatzeko. Horretarako, beharrezkoa da egiten den eskaintza zaintzea. Kalitatezko kanpo espazioak esplorazioa eta esperimentazioa bultzatu behar du. Edozein kasutan, diseinua ez da kalitatezko espaziorako baldintza bakarra (Ardanaz, 2009; Davies, 1997; Karin eta Wright, 2014), irakaslearen rola funtsezkoa baita espazio horri erabilera egokia emateko.

\subsection{Irakaslearen rola kanpo espazioan}

Barne zein kanpo espazioetan irakaslearen rola beharrezkoa da eskuhartze egokien bidez haurren beharrei erantzun egokia emateko (Barandia- 
ran, Muela, Lopez de Arana, Larrea eta Martinez, 2015). Behar horien artean haurren interes eta jakin-mina dago eta garrantzitsua da irakaslearen esku-hartzea interes horiei tira eginda haurren garapen eta ikaskuntza prozesuak bultzatzeko (Davies, 1997; Rengel 2014).

Daviesek (1997) zehazki zioen irakasleek haurren garapenean eta ikaste- prozesuan eragina dutela, eta, hori dela eta, aipatu zuen irakasleek egiten dituzten esku-hartzeak zaindu behar dituztela. Irakaslearen rola beharrezkoa izan arren, horrek ez du esan nahi irakasleek estrategia eta esku-hartze gehiegi egin behar dituztenik, baizik eta haurren beharren arabera jokatu behar dutela. Horrez gain, garrantzitsuak dira irakasleek haurrekin izaten dituzten elkarrekintzak (Davies, 1997) eta horregatik garrantzitsua da horiek zaintzea (Barandiaran et al., 2015). Elkarrekintza egokiak izateko, batetik, irakasleak haurra ezagutu behar du eta, bestetik, zenbait estrategia izan behar ditu (Davies, 1997; Frontela, 2013).

Estrategia horietako batzuek ez dute inolako elkarrekintzarik behar, adibidez, haurra behatzeak; beste batzuek, ordea, bai, haurren akzioei eta beharrei erantzuna emateko. Azken horiek dira hain zuzen zaindu behar direnak haurraren garapen integrala ziurtatzeko.

Haurraren ezagutzatik estrategia egokiak menperatzearen ideia bat dator sentikortasunaren kontzeptuarekin (Barandiaran et al., 2015; Garcia, 2009). Erantzun sentikorrek bere baitan hartzen dute haurraren emozioak kontuan hartzea, haurrei arreta indibidualizatua eskaintzea eta haurren beharrei edo premiei erantzun egokia ematea (Barandiaran, et al., 2015; Garcia, 2009).

Irakaslearen erantzun sentikorrak bat datoz enpatiarekin, errespetuan oinarritutako jarrerarekin eta haurraren garapenaren sustapenarekin (Frontela, 2013). Elkarrekintza horietan, irakasleak gorputz adierazpena, isiluneak, eta komunikazio berbala erabili behar ditu, baina esan bezala, garrantzitsua da jakitea estrategia bakoitza nola eta noiz erabili; Azken batean, haurren beharrei eta interesei era aproposean erantzuna ematea lortzen duten irakasleek sustatuko baitute haurraren garapen integrala eta ikaskuntza esanguratsua (Davies, 1997; Garcia, 2009; Segura, 2005).

Hortaz, kanpo espazio hori diseinatu aurretik haurren interesak kontuan hartu behar dira giro erosoa sortzeko. Jolasteko, esploratzeko eta ikasteko toki esanguratsuak sortu behar dira, betiere haurraren adinera egokituta. Toki horiek sortzeko material aproposak erabili behar dira, segurtasuna bermatzeko eta umearen gaitasunak garatzeko. Horretarako, egokienak dira material naturalak, eta manipulazioa, zentzumen anitzen bidezko esplorazioa zein mugimendua ahalbidetzen dutenak. Azken batean, jolas anitzak baimentzen dituzten espazio zabalak sortu behar dira aipatutakoa garatu ahal izateko (Debord et al., 2005; Fdzila eta Said, 2010: Karin eta Wright, 2014; Olse, 2013; Parsons, 2011;). Azkenik, behin kanpo espazioa diseinatuta, berebiziko garrantzia du irakasleak hartzen duen rolak haurren beharrei erantzun egokia eman eta hortik espazioaren erabilera egokia sus- 
tatzeko (Barandiaran et al., 2015; Davies, 1997; Frontela, 2013; Garcia, 2009).

Kanpo espazioaren kalitaterako aldagai esanguratsuak dira irakaslearen rola eta kanpo espazioaren diseinua. Gainera, ikerketak, oro har, bat datoz kanpo espazioaren garrantzia aldarrikatzeko orduan. Ildo horretatik, azpimarratzekoa da haurraren garapenean eragiteko duen gaitasunagatik, kanpo espazioaren kalitatea zaindu beharrekoa dela. Ikerketa honek, hain zuzen, kanpo espazioaren kalitatea eta garapenaren adierazletzat har daitekeen jolasaren arteko harremanean sakondu nahi du, ikusirik gure testuinguruan ez direla asko bi ardatz horietan sakondutako lanak. Zehazki, ikerketa honen helburua da berrikuntzak egitea eta beren balioa egiaztatzea Bizkaiko ikastetxe bateko kanpo espazioan, haurraren garapenerako testuinguru aproposagoa izan dadin. Ikerketa honekin espero da Haur Hezkuntzako ikastetxe horren kanpo espazioan egingo diren berrikuntzek bere kalitatea hobetzea, eta jolas mota anitzagoak egotea, hau da, jolasean aldaketak eragitea.

\section{METODOLOGIA}

Kanpo espazioan egingo diren berrikuntzen inpaktua ebaluatzeko, metodo mistoa erabili da, Harrisonek (1992) dioenez, metodologia kuantitatiboa eta kualitatiboa uztartzea aberasgarria delako. Harrisonen (1992) ustez, lau indar daude bi metodologia horiek beharrezkoak egiten dituztenak: ikerketa metodoak banaezinak izatea, ulermen maila handiagoa izatea, ikertzaileen curriculumaren garapena eta balio zientifikoa izatea. Beraz, ideia horiek aintzat harturik, metodo mistoa jarraitu da; batetik, metodologia kualitatiboa baliatu da haurren jolasak jasotzeko; eta, bestetik, datu kuantitatiboen bidez jaso da kanpo espazioaren kalitatea.

\subsection{Parte-hartzaileak}

Ikerketan Bizkaiko erdialdeko herri batean kokatutako ikastetxe batek parte hartu du, ikerketan bere interesa adierazi eta gero. Ikastetxean bi kanpo espazio dauden arren, ikerketa egiteko guztiz estali gabekoa erabili da, The Institute for Outdoor Learning-IOL erakundearen (2011) erakundearen izapideak jarraituta.

Nahiz eta ikastetxeak beste hezkuntza etapa batzuk eskaini, soilik Haur Hezkuntzako 4 urteko gela bateko haurrek eta tutoreak parte hartu dute. Gela zoriz hautatu eta gero, zehazki 26 haurrek eta irakasle batek hartu dute parte. 26 haur horietatik 14 neskak ziren eta gainerako 12ak mutilak. Irakasleari dagokionez, Haur Hezkuntzako irakasle ikasketadun 55 urteko emakumezkoa zen, hezkuntza arautuan 34 urteko eskarmentua duena. 


\subsection{Datuak jasotzeko teknikak}

Datuak jasotzeko nagusiki bi teknika erabili dira: jolasa zerrendatzeko behaketa sistematikoa eta kanpo espazioen kalitatea ebaluatzeko Preschool Outdoor Environment Measurement Scale (POEMS) (Debord et al., 2005).

\section{Jolasa zerrendatzeko behaketa sistematikoa}

Batetik, behaketa sistematikoak egin dira azaltzeko haurrek kanpoan zer egiten duten. Zehazki haurrak zertan, nola eta zein materialekin jolasten diren identifikatu da behaketaren bidez. Horretarako, kanpo espazioa erabiltzen zuten tarteetan, errealitatera gerturatu eta haurrak ardatz hartu dira behaketak egiteko. Zehazki, hiru egunetan zehar 30-40 minutu erabili dira haurrak zertan, nola eta zein materialekin jolasten diren identifikatzeko. Horrela, behaketetan ikerlariek haurren jolasen zerrenda osatu zuten.

\section{Preschool Outdoor Enviroment Measurement Scale (POEMS) tresna}

Bestetik, ikastetxeetako kanpo espazioaren kalitatea ebaluatzeko Preschool Outdoor Environment Measurement Scale-POEMS erabili da (Debord et al., 2005). Eskala honek Haur Hezkuntzako kanpo espazioaren kalitatea neurtzen du. Horretarako, POEMS eskalak 56 item dauzka, ondoko 5 dimentsioetan banatuta: (1) Ingurune fisikoa, (2) Elkarrekintzak, (3) Ikasteko eta jolaserako konfigurazioa, (4) Programa eta (5) Irakaslearen rola. Ikerketa honetarako, ingurune fisikoari dagokion dimentsioa eta bere 13 itemak baztertu egin dira, aldagai finkoagoak diren heinean, bertan berrikuntzak egiteko aukerak urriak direlako.

Aztertutako dimentsioei dagokienez, lehenik argitu behar da elkarrekintza dimentsioak 13 item dituela eta, horien bitartez, aztertzen direla haurrek bere berdinkideekin, irakaslearekin eta material eta objektu naturalekin izaten dituzten elkarrekintzak. Horretaz gain, familiek eta irakasleak dituzten elkarrekintzak ere aintzat hartzen dira.

Bigarrenik, ikasteko eta jolasteko konfigurazioari dagokion dimentsioan 13 item daude. Dimentsio hori baliagarria da kanpo espazioetan jolasteko eta ikasteko espazioen eta materialen egokitasuna aztertzeko. Besteak beste hobesten dira espazioan ongi bereizitako jolasteko eta ikasteko proposamen anitzak.

Hirugarrenik, programari dagokion dimentsioak 9 item ditu eta kanpo espazioaren integrazio curricularrari egiten dio erreferentzia. Kanpo espazioaren diseinua eta erabilera curriculumaren barne dagoen aztertzen da, nolabait kanpo espazioa baliabide pedagogiko moduan ulertzen den aztertzeko.

Laugarrenik, eta azkenik, irakaslearen rolean oinarritutako dimentsioa dago. Bere 8 itemetan, arreta jartzen da irakaslearen eta, oro har, hezkuntza 
komunitatearen inplikazioan kanpo espazioan. Horrez gain, dimentsio honetan aztertzen dira irakaslearen rola (segurtasuna bermatzea, autonomia eskaintzea eta abar) eta bere esku-hartzeak kanpo espazioan diseinu berriak sortzeko eta txertatzeko.

POEMS eskalaren aplikazioa egiteko, behaketaren bidez, dimentsio bakoitzeko itemak betetzen ziren edo ez aztertzen da. Behaketaren bidez ikusten ez dena, elkarrizketa bidez galdetzen zaio ikastetxeko koordinatzaileari edo irakasleari. Betetze mailaren arabera, ehunekoa kalkulatzen da dimentsio bakoitza ardatz izanda. Azkenik, esan behar da POEMS tresnak, bere bost dimentsio horiekin, barne trinkotasun egokia erakusten duela eta edukien baliozkotasun egoki eta bateratua duela (DeBord et al., 2005).

\subsection{Prozedura}

Ikerketa hiru fase nagusitan bideratu zen helburuei eta hipotesiei erantzun egokia emateko, hain zuzen, baieztatzeko edo ezeztatzeko berrikuntza dela medio, kanpo espazioaren kalitatea handitzen den eta jolas mota anitzagoak dauden. Horretarako, lehenik eta behin, Amorebieta-Etxanoko ikastetxean proiektua aurkeztu zen, hainbat bilera egin ziren eta jakinarazi zen konfidentzialtasuna bermatukoa zela, abenduaren 13ko 15/1999 Lege Organikoak, Izaera Pertsonaleko Datuak Babesteko legeak dioen moduan. Behin zentroaren parte-hartzea baieztatu ostean ikerketako lagina zoriz aukeratu zen, eta datu bilketarekin hasi zen.

Horretarako, kanpo espazioaren argazkiak atera ziren Haur Hezkuntzako jolastokiaren deskribapena egiteko, horrekin errealitatearen inguruko informazioa jaso nahi zen eta ikertzaileak testuinguru horretan kokatu. Ondoren, errealitatearen datu gehiago jaso ziren, hain zuzen, hiru egunetan zehar 30-40 minutuz jolasaren behaketak egiteari eta kanpo espazioaren kalitatearen neurketari ekin zitzaien. Horretarako kanpoan zeuden bitartean, Haur Hezkuntzako lau urteko gelako haurrak eta bertako tutoreak behatu ziren, jolasaren behaketa sistematikoa egiteko eta POEMS eskalako itemak egiaztatzeko. Kanpo espazioaren erabilera amaitzean, irakasleari edo koordinatzaileari galdetzen zitzaien POEMSeko behagarriak ez ziren itemei buruz.

Ikastetxearen oniritzia jaso eta errealitateari buruzko datuak jaso eta aztertu ostean, ikerketaren bigarren faseari hasiera eman zitzaion. Fase honetan, berrikuntza proposamena diseinatu zen. Beraz, errealitateko emaitzak kontuan izanda eta horiek aztertuta, berrikuntzari buruzko hausnarketa egin zen, aintzat harturik jolasaz eta kanpo espazioaren kalitateaz izandako emaitzak eta aurrekarien atalean adituek egindako ekarpenak. Horrenbestez, berrikuntzarako proposamena egin zen antzemandako hutsuneei irtenbidea emateko eta haurren jolasa eta esperimentazioa sustatzeko eskaintza 
zabala egitea ardatz zela. Halaber, haurren adina eta ezaugarriak ere aintzat hartu ziren eta, horren guztiaren ondorioz, jolasa sustatzeko eskaintza zabala islatu zen hainbat gune berriren proposamenean. Hurrengo taulak jasotzen ditu berrikuntzarako gune bakoitzaren oinarriak:

\section{Berrikuntzarako guneak}

\begin{tabular}{|c|c|c|}
\hline Gunea & Zertan datza? Zer lortu nahi da? & Materialak \\
\hline $\begin{array}{c}\text { 1. Artea } \\
\text { eta musika } \\
\text { jarduerak eta } \\
\text { eszenatokia }\end{array}$ & $\begin{array}{l}\text { Gune honen bitartez, aska- } \\
\text { tasunez, ondokoak sustatu nahi } \\
\text { dira: sormena, esplorazioa es- } \\
\text { perimentazioa, erritmoa, entzu- } \\
\text { mena, koordinazioa, motrizitate } \\
\text { fina, eta hizkuntza lantzea. } \\
\text { Horretarako proposatuko da: } \\
\text { artea lantzeko materialak, esze- } \\
\text { natoki bat (salto egiteko, dantza } \\
\text { egiteko, abesteko...) eta musika } \\
\text { sortzeko aukera, hainbat mate- } \\
\text { rialekin. }\end{array}$ & $\begin{array}{l}\text { Zerazko margoak, tenperak, } \\
\text { klarionak, forma, kolore tamaina } \\
\text { eta testura ezberdineko orriak. } \\
\text { Paleak eszenatokia egiteko. } \\
\text { Platerak lehortzeko materiala } \\
\text { (egitura ezberdinekin), kuboa } \\
\text { (plastikozko danbor moduan), } \\
\text { egur zatia (egitura ezberdina } \\
\text { duena, ez da planoa), egurrezko } \\
\text { makila batzuk, plastikozko hodi } \\
\text { txikiak garbantzuekin, txirlekin, } \\
\text { arrozarekin. }\end{array}$ \\
\hline $\begin{array}{l}\text { 2. Jolas } \\
\text { sinbolikoa }\end{array}$ & $\begin{array}{l}\text { Jolas sinbolikoan, rol aldaketa } \\
\text { eta fantasia, jolasteko aukera es- } \\
\text { kaini nahi da, haurraren garapen } \\
\text { kognitiboa eta afektiboa sustatuz. } \\
\text { Hain zuzen, rol aldaketarekin } \\
\text { sormena eta hizkuntza lantzea } \\
\text { espero da, ezagutza berriak esku- } \\
\text { ratzen dituzten bitartean. }\end{array}$ & $\begin{array}{l}\text { Egituratutako materialak: } \\
\text { trena, itsasontzia. } \\
\text { Egituratu gabeko materialak: } \\
\text { oihal zatiak eta kaxak. }\end{array}$ \\
\hline $\begin{array}{l}\text { 3. Material } \\
\text { sentsorialak: } \\
\text { 3.1. Material } \\
\text { solteak }\end{array}$ & $\begin{array}{l}\text { Esperimentazioa lantzeko } \\
\text { pieza solteak eskainiko dira. } \\
\text { Horiek kaxa batzuetan gordeta } \\
\text { egongo dira etiketa batzuekin } \\
\text { sailkapenak lantzeko. } \\
\text { Horretaz gain, espero da on- } \\
\text { dokoak sustatzea: esperimen- } \\
\text { tazioa, esplorazioa, motrizitate } \\
\text { fina, sormena, koordinazioa, me- } \\
\text { moria eta eraikuntza jolasak. }\end{array}$ & $\begin{array}{l}\text { Estruktura gabeko materialak: } \\
\text { pinaburuak, errekako harriak, } \\
\text { makila txikiak, kaxak eta mate- } \\
\text { rial fabrikatuak: baloia, uztaiak } \\
\text { eta soka. }\end{array}$ \\
\hline
\end{tabular}




\begin{tabular}{|c|c|c|}
\hline Gunea & Zertan datza? Zer lortu nahi da? & Materialak \\
\hline $\begin{array}{c}\text { 3. Material } \\
\text { sentsorialak: } \\
3.2 . \\
\text { Usaintzeko } \\
\text { poteak }\end{array}$ & $\begin{array}{l}\text { Hainbat gauza usaintzeko au- } \\
\text { kera eskaini nahi da. Jolas sen- } \\
\text { tsoriala proposamen guztian age- } \\
\text { rian egon arren, honekin nahi da } \\
\text { usaimenari berariazko aukera } \\
\text { ematea. Era berean, esperimenta- } \\
\text { zioa ere landu nahi da. }\end{array}$ & $\begin{array}{l}\text { Poteak, irudiak, eta usaintzeko } \\
\text { hainbat material: Sagarra, kokoa } \\
\text { eta marrubia. }\end{array}$ \\
\hline $\begin{array}{c}4 . \\
\text { Kanpo-barne } \\
\text { konexioa eta } \\
\text { lasaitasuna }\end{array}$ & $\begin{array}{l}\text { POEMS eskalak proposatzen } \\
\text { duen irizpide bat da lotura egotea } \\
\text { kanpokoaren eta barruko dinami- } \\
\text { ken artean. Hori dela eta, lasai- } \\
\text { tasun gune bat sortu da, kanpo- } \\
\text { barne konexio hori egiteko. Hori } \\
\text { aprobetxatuz, lasaitasun gune bat } \\
\text { sortu da, trantsizio moduan. }\end{array}$ & Lau ipuin. \\
\hline $\begin{array}{l}5 . \\
\text { Matematika } \\
\text { eta zientzia }\end{array}$ & $\begin{array}{l}\text { Jaso, sailkatu, ordenatu, lan- } \\
\text { tzeaz gain, lupak eta zinta metri- } \\
\text { koa egongo dira, haurrek horiekin } \\
\text { esperimentatu ahal izateko. Hala } \\
\text { ere, egingo den eskaintzarekin } \\
\text { etengabe matematika era inpli- } \\
\text { zituan landu dezakete, tamaina, } \\
\text { pisu, forma ezberdineko materia- } \\
\text { lak etengabe eskainiko direlako. }\end{array}$ & $\begin{array}{l}\text { Zehazki: lupak, zinta metri- } \\
\text { koa. } \\
\text { Hala ere, material horiek beste } \\
\text { gune batzuetako materialekin } \\
\text { erabiltzeko aukera dago, horien } \\
\text { pisua, forma edo tamaina aztertu } \\
\text { ahal izateko. }\end{array}$ \\
\hline $\begin{array}{l}\text { 6. Oreka } \\
\text { lantzeko } \\
\text { gunea }\end{array}$ & $\begin{array}{l}\text { Garapen motorrari begira be- } \\
\text { reziki, egitura ezberdinetako en- } \\
\text { bor zatiak proposatuko lirateke. }\end{array}$ & Enborrak \\
\hline $\begin{array}{l}\text { 7. Elementu } \\
\text { apaingarriak }\end{array}$ & $\begin{array}{l}\text { Elementu apaingarri, kolore- } \\
\text { tsu eta estimulagarriak ipintzea } \\
\text { proposatu da, POEMSeko irizpi- } \\
\text { deetako bat baita. }\end{array}$ & Banderak eta haize orratza. \\
\hline
\end{tabular}

Behin berrikuntzari zegozkion baliabideak jarri zirela, hasiera eman zitzaion ikerketaren hirugarren faseari. Hain zuzen ere, berritutako kanpo espazioan lehenengo fasean jarraitutako prozesu bera errepikatu zen. Hortaz, batetik, hiru egunetan 30-40 minutuz jolasaren behaketak egin ziren haurrak zertan, nola eta zein materialekin jolasten ziren jasotzeko. Bestetik, POEMS eskalaren bidez kanpo espazioaren kalitatea neurtu zen 4 urteko 
gela bateko haurrak eta tutorea bertan zeudela. Lan guztiekin amaitutakoan, datuak interpretatu eta aztertu ziren.

\section{EMAITZAK}

\subsection{Kanpo espazioaren kalitatea}

Ikerketaren diseinuan adierazi bezala, kanpo espazioaren kalitatea aztertu zen berrikuntza egin aurretik eta ondoren. Kalitatea ebaluatzeko, POEMS eskalaren lau dimentsio aintzat hartu ziren: Elkarrekintzak, Ikasteko eta jolaserako konfigurazioa, Programa eta, azkenik, Irakaslearen rola. Hurrengo taulak biltzen ditu berrikuntzaren aurretik eta ondoren izandako emaitzak kanpo espazioaren kalitateari dagokionez:

2. taula

\section{Kanpo espazioaren kalitatea dimentsioka}

\begin{tabular}{l|c|c|c|c|c|c}
\hline & \multicolumn{2}{|c|}{ Berrikuntzaren aurretik } & \multicolumn{3}{c}{ Berrikuntzaren ostean } \\
\cline { 2 - 7 } & $\begin{array}{c}\text { Item } \\
\text { kopurua }\end{array}$ & $\begin{array}{c}\text { Betetako } \\
\text { item } \\
\text { kopurua }\end{array}$ & Emaitza & $\begin{array}{c}\text { Item } \\
\text { kopurua }\end{array}$ & $\begin{array}{c}\text { Betetako } \\
\text { item } \\
\text { kopurua }\end{array}$ & Emaitza \\
\hline Elkarrekintza & 13 & 6 & $\% 46.50$ & 13 & 8 & $\% 61.53$ \\
\hline $\begin{array}{l}\text { Ikasteko eta jolase- } \\
\text { rako konfigurazioa }\end{array}$ & 13 & 6 & $\% 46.50$ & 13 & 10 & $\% 76.92$ \\
\hline Programa & 9 & 4 & $\% 44.44$ & 9 & 7 & $\% 77.77$ \\
\hline Irakaslearen rola & 8 & 3 & $\% 37.50$ & 8 & 3 & $\% 37.50$ \\
\hline
\end{tabular}

2. taulan ikus daiteke berrikuntza egin aurretiko kalitatea baxua zela. Dimentsio guztiak \% 50eko emaitzaren azpitik zeuden. Zehazki, elkarrekintzei dagokien dimentsioan \% 46.5eko emaitza zegoen, elementu naturalekin esperimentatzeko, jakin-mina sustatzeko eta haurren arteko harremana bultzatzeko baliabide eta ekintza gutxi baitzeuden. Ikasteko eta jolaserako konfigurazioari bagagozkio, \% 46.5eko emaitza jaso zen berrikuntzaren aurretik, baliabide eskasiagatik bereziki. Programaren dimentsioari erreferentzia eginez, \% 44.44ko emaitza jaso zen berrikuntzaren aurretik, nagusiki kanpo espazioaren erabilera ez zegoelako curriculumean txertatuta. Azkenik, irakaslearen rolari dagokionez, berrikuntzaren aurretiko emaitza\%37.5era mugatu zen. Emaitza horren atzetik irakaslearen eta komunitateko kideen partaidetza mugatuta zegoen. 
Kanpo espazioari dagozkion emaitza baxuak aztertu eta gero, berrikuntza indarrean jarri zen. Berrikuntza osteko emaitzei dagokienez, ondoko irudiak argi uzten du dimentsio gehienetan izandako progresioa.

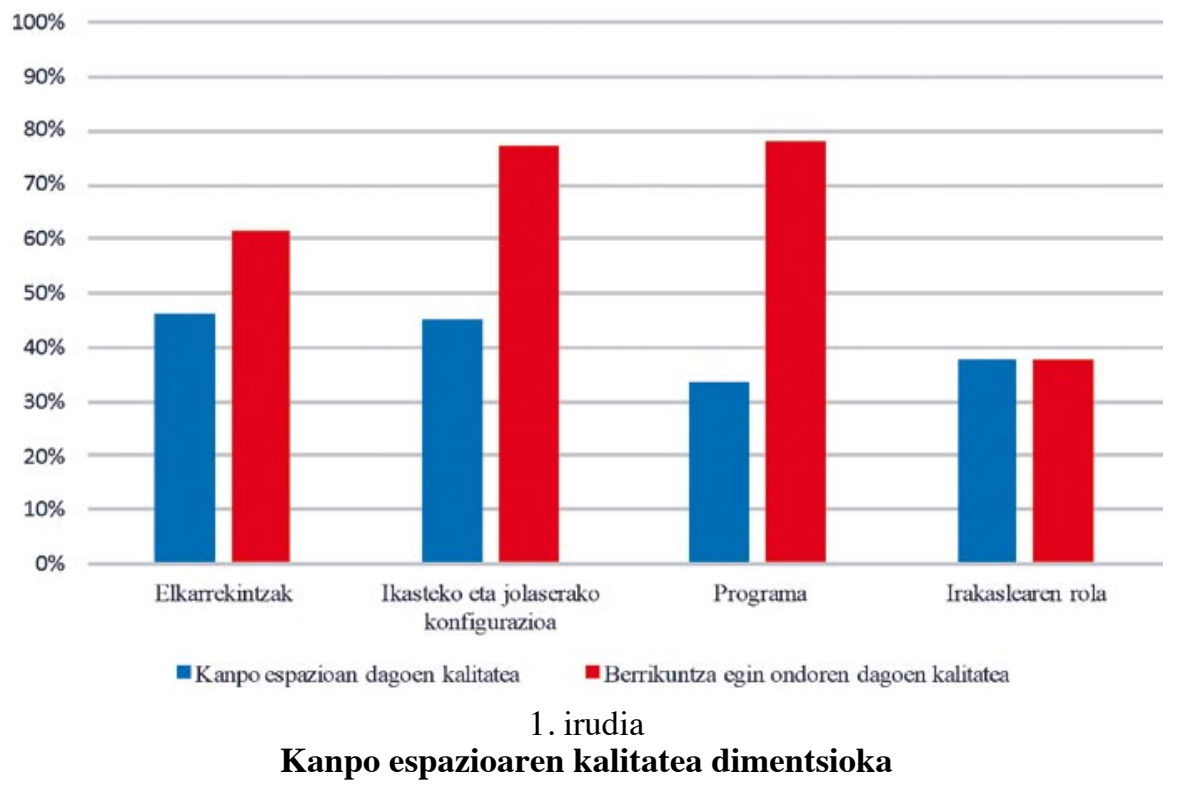

Izandako progresioari erreparatuta eta elkarrekintzei dagokien dimentsioari dagokionez, emaitza \%46.50etik \%61.53ra igo da. Ikaskuntzarako eta jolaserako konfigurazioari erreparatuz gero, \%76.92ra hobetu da kalitatearekin lotutako emaitza, berrikuntzaren aurretik baino 30 puntu gorago, alegia. Programari dagokionez ere, $\% 44.44 \mathrm{ko}$ kalitate emaitzatik \%77.77rainoko igoera egon da. Azkenik, irakaslearen rolari dagokion dimentsioaren emaitzetan ez dago alderik (\%37.5), berdin jokatzen jarraitu baitu irakasleak eta inplikazio maila berbera baitaukate komunitateko kide guztiek berrikuntzaren aurretik eta ondoren.

\subsection{Haurraren jolasa}

Jolasari dagokionez, prozedura atalean azaldu bezala, behaketa sistematikoaren bidez identifikatu da haurrak zertan, nola eta zein materialekin jolasten diren, hala berrikuntza egin aurretik, nola ondoren. 3. taulak islatzen ditu kanpo espazioan berrikuntza egin aurretiko haurraren jolasaren ezaugarriak. 
3. taula

Berrikuntzaren aurretiko jolasa

\begin{tabular}{|c|c|}
\hline Tokia & Haurrek egiten dutena \\
\hline Futbol zelaiaren testuingurua & $\begin{array}{l}\text { Futbolean jokatu } \\
\text { Itzulipurdika ibili } \\
\text { Zomorroak harrapatu eta ikusi } \\
\text { Bazterrera igo } \\
\text { Pilotan jokatu } \\
\text { Futbol zelaiko sarea hartu }\end{array}$ \\
\hline $\begin{array}{c}\text { Hainbat kulunka } \\
\text { (txirrista, igotzeko, kulunkak...) } \\
\text { dauden testuingurua }\end{array}$ & $\begin{array}{l}\text { Uztaiak pasatu } \\
\text { Kulunkatu } \\
\text { Solairura igo, jaitsi, korrika egin. } \\
\text { Enborreko aldapatik pasa edo igo } \\
\text { Harrapatzera jolastu } \\
\text { Igotzea edo gora egitea } \\
\text { Txirristatik igo eta bertatik jaitsi } \\
\text { Pilotan jokatu } \\
\text { Saltoak egin }\end{array}$ \\
\hline
\end{tabular}

3. taulan ikus daitekeen moduan, berrikuntza egin aurretik, haurrak bi testuinguru ezberdinetan jolasten ziren, futbol zelaian eta kulunketako espazioan. Lehenengo espazioan, ikusi zen haurrak jolasten zirela futbolean, itzulipurdika ibiltzen, bertan zegoen bazterrera igotzera eta hortik ibiltzera, sarea ipintzera zein kentzera, zomorroak bazter batean aurkitzera, hartzera eta horiek beste toki batera eramatera, eta pilotarekin futbol zelaian futbola ez zen beste jolas batzuetara jolasten zirela.

Kulunketako testuinguruan, ordea, bertako eskaintzara zehatzago egokitutako jolasak ematen ziren: uztaiak igarotzera, kulunkatzera, solairura igotzera eta bertatik korrika egitera, egitura barnean dauden enborrak pasatzera, txirristatik jaistera, batak bestea harrapatzera, pilotarekin txirristatik botatzera eta saltoak egitera.

Beraz, berrikuntza aurretiko azterketak aditzera ematen du batez ere mugimenduarekin lotutako jolasak nagusi zirela eta, bitartean, esploraziorako, manipulaziorako edo esperimentaziorako joera mugatua zela, zomorroekin behatutako jardunaren salbuespenarekin. Egoera horretatik abiatuta, berrikuntza proposamenak diseinatu eta indarrean jarri ziren. Berriz ere haurren jolasa behatzerakoan, ondoko taulak islatutako ekintzak ikusi ziren haurren partetik.

4. taulan ikus daitekeenez, berrikuntza proposamena egin ondoren, haurrek egiten dutenetan aldaketa egon zen. Batetik, berrikuntzaren aurretiko jolasa modu orekatuan banatzen zen futbol zelaiaren eta kulunken 
4. taula

Berrikuntzaren osteko jolasa

\begin{tabular}{|c|c|}
\hline Tokia & Haurrek egiten dutena \\
\hline $\begin{array}{l}\text { Futbol zelaiaren } \\
\text { testuingurua }\end{array}$ & Lupak hartu: zomorroak ikusi eta hartu. \\
\hline \multirow{11}{*}{$\begin{array}{l}\text { Hainbat } \\
\text { kulunka dauden } \\
\text { testuingurua }\end{array}$} & Enbor gunea: Saltoak egin eta material solteak sailkatu. \\
\hline & $\begin{array}{l}\text { Margotzeko gunea: Margotu lurrean, hainbat formatako } \\
\text { orrietan, tenperekin, errotulagailuekin, zerekin eta klarionare- } \\
\text { kin. Horiek guztiak nahasten ere. }\end{array}$ \\
\hline & $\begin{array}{l}\text { Material solteak: Pinaburuak, harriak, makila leunak, egu- } \\
\text { rrak jaso, bota, sailkatu eta zenbatu. } \\
\text { Orekako enborretan: materialak jaso, bota sailkatu (pina- } \\
\text { buruak, egurrak, makila leunak...) }\end{array}$ \\
\hline & $\begin{array}{l}\text { Jolas sinboliko gunea: Itsasontziak, kapitainarena egin. } \\
\text { Oihalak (Superman) } \\
\text { Material solteak (sua egin, barbakoa egin eta supermerka- } \\
\text { tua). }\end{array}$ \\
\hline & $\begin{array}{l}\text { Fruta kaxekin: Ibilbideak egin.Kaxak batu. } \\
\text { Ibilbide luzea orekako enborrekin. }\end{array}$ \\
\hline & Itsasontziak: Arrastatu. Lasterketak egin. \\
\hline & Musika gunea: Musika jo. \\
\hline & Usaintzeko gunea: Poteak usaindu. \\
\hline & Lasaitasun gunea: Ipuinak ikusi eta irakurri. \\
\hline & Lupak hartu: Harriak ikusi. Belarreko zomorroak ikusi. \\
\hline & $\begin{array}{l}\text { Kanpo espazioaren egituran: Igo eta eskalatu. } \\
\text { Uztaiak egin. Azazkalak margotu. }\end{array}$ \\
\hline
\end{tabular}

testuinguruaren artean. Berrikuntzaren ostean, berriz, kulunken inguruan eman ziren haurren jolas ekintza gehienak. Bestetik, zehazki haurrek egiten dutenari erreparatuz gero, berrikuntzaren ostean anitzagoa da haurraren jolasa. Berrikuntzaren aurretiko hainbat jolas errepikatu dira, kulunketan eta uztaietan ibiltzea edo igotzea kasu, baina beste jolas berri batzuk behatu ahal izan dira berrikuntzarekin.

Adibidez, bereziki mugimenduarekin - eta batzuetan eraikuntzekinlotutakoak, lurrean jarritako enborretatik saltoak egin zituzten; fruta ka- 
xekin ibilbideak eraiki eta bertatik saltoak egin zituzten; fruta kaxak eta enborrak uztartuta maila ezberdinetako ibilbide luzea ere egin zuten; eta jarritako itsasontziak arrastaka eramaten zituzten eta lasterketak egiten zituzten. Bestalde, haurrak margotzen behatu ziren, errotulagailuekin, klarionekin edo tenperekin, eskuekin eta pintzelekin eta lurrean edo paperean.

Jolas sinbolikoari dagokionez, haurrek itsasontziak, oihalak, eta egituratu gabeko materialen bidez, hainbat egoera eta pertsonaia irudikatzen ikusi ahal izan ziren. zehazki, barbakoak eta sua egiten eta Supermanen, itsasontzi barruan zihoan kapitain baten edo supermerkatu bateko dendari eta eroslearen rolak hartzen. Are gehiago, material solteekin jolas sinbolikoa egiteaz gain, eraikuntzak ere sortu zituzten.

Hain zuzen ere, material solteekin egindako behaketek haurren ekintza ugari agerian utzi zuten, ukitzea, manipulatzea, botatzea, jasotzea, sailkatzea edo zenbatzea kasu. Musika eta usaintzeko guneetan, berriz, haurrak musika egiten eta hainbat usain usaintzen ikusi ziren.

Lasaitasunaren gunean haur gutxi batzuek ipuinak irakurri zituzten edo, soilik bertan jesarrita lasai egon ziren. Azkenik, berrikuntzan aurreikusi ez zen jolas edo ekintza bat ere jaso zen: atzazkalak margotzea.

Futbol zelaiko testuinguruari dagokionez, eskainitako lupak erabili zituzten zomorroak behatzeko. Aipatzekoa da behaketek iraun bitartean haurrek ez zutela eskainitako pilotarik hartu eta beste eskaintzak hobetsi zituztela.

Beraz, berrikuntza egin aurretik eta ondoren aldaketak egon dira jolasean. Mugimenduarekin eta futbolarekin lotutako jolasetatik, anitzagoak diren ekintzetara igaro dira haurrak. Behaketen arabera, mugimenduari gehitu zaizkio jolas sinbolikoa, eraikuntza jolasa eta era ezberdinetako esperimentazioak.

\section{EZTABAIDA}

Ikerketa honen helburua zen aztertutako ikastetxeko Haur Hezkuntzako kanpo espazioa haurren garapenerako testuinguru aproposagoa izatea. Zehazki espero zen berrikuntza egitean kanpo espazioaren kalitatea hobetzea eta jolas mota anitzagoa egotea.

Ikerketaren lehenengo faseari esker ikusi ahal izan da aztertutako kanpo espazioaren abiapuntua zein zen. Batetik, POEMS eskalan jasotako dimentsio guztietan kalitatea \%48ren azpitik zegoen. Gainera, solik joaten ziren kanpo espaziora 30 minutu inguru, beraz, ez zuten Olsek (2013) proposatzen duen erabilera sistematikoa egiten. Are gehiago, haurrek ez zuten egun guztietan kanpora joateko aukerarik izaten, adibidez, euriarekin barruko espazioan gelditzen baitziren. Bestetik, jolasari dagokionez, haurrak futbolean edo kulunketan (txirristak, solairua..) dagoen eskaintzara soilik jolasten ziren. Ondorioz, garrantzitsua den mugimendua ematen zen baina 
oso mugatuta zeuden beste jolas mota batzuetarako eta esperimentaziorako aukerak. Gainera, Karinek eta Wrightek (2014) aldarrikatutako jolaserako aukera anitzik eta material solterik ez zegoen. Beraz, errealitatean, aukera gutxi zituzten jolas anitzetan aritzeko, esploratzeko, esperimentatzeko, material solteekin jolasteko eta naturarekin harremana izateko. Horrenbestez, kanpo espazioaren kalitatea mugatua zen, hainbat autorek aldarrikatutako irizpideetatik urrun baitzegoen aztertutako kanpo espazioa (DeBord et al., 2005; Kos eta Jerman 2013, Luchs eta Fikus, 2013).

Berrikuntza proposamena martxan ipini ondoren, ordea, kanpo espazioaren kalitatea igo egin zen. POEMS eskalako dimentsio guztietan, irakaslearen rolari dagokionean izan ezik, \% 60tik gorakoa , alegia, maila ertaineko kalitate emaitzak erdietsi ziren.

Dimentsio zehatzetara joz gero, elkarrekintza dimentsioari dagokionez, emaitzak nabarmen gora egin du, bereziki, haurrak berdinkideekin eta material eta objektu naturalekin izandako elkarrekintzetan. Zehazki, ikusi da haurrak bere berdinkideekin elkarrekintza gehiago izan dituela. Behaketek agerian utzi dute haurren elkarrekintzan oinarritutako jolas gehiago, jolasa partekatu baitute eta elkarri gehiago hitz egin baitiote (Rubin et al., 1983). Ildo beretik, emaitzaren gorakadaren arrazoien artean aipa behar da haurraren motibazioa bere berdinkideekin aritzeko (Coplan et al., 2006). Zentzu horretan, esan daiteke berrikuntzaren osteko kanpo espazioak jolas sozialerako abagunea indartu duela (Coplan et al., 2006). Era berean, haurrak aukera gehiago izan du naturarekin edo elementu naturalekin elkarrekintzak izateko, hainbat autorek aldarrikatutako inguru naturalari gehiago hurbildu baitzaio berrikuntzaren osteko kanpo espazioa (Kos eta Jerman, 2013; Luchs eta Fikus, 2013). Aitzitik, dimentsio honetan emaitza altuagoa lortzeko, ezinbestekoa da haurraren eta irakaslearen arteko elkarrekintzak hobetzea. Behaketek agerian utzi dute aukerak daudela irakaslea haurraren elkarrizketei, beharrei eta interesei adiago egoteko eta, horrela, haurraren interesei eta jakin-minei hobeto erantzuteko (Davies, 1997; Rengel, 2013). Irakasleak haurraren garapena (Barandiaran et al., 2015) eta ikaste prozesua (Davies, 1997) baldintzatzeko daukan ahalmena ikusirik, garrantzitsua da irakaslearen zein familiaren esku-hartzeaz gogoeta sakona egitea.

Ikasteko eta jolaserako konfigurazioa deritzon dimentsioari erreparatuta, elkarrekintzei dagokienean baino emaitza altuagoa jaso zen. Halaber, berrikuntzaren aurretiko emaitza nabarmen hobetu zen. Emaitza horien atzean dago berrikuntzan baliabide anitzak eskaintzea (Moser eta Martinsen, 2012; Olse, 2013). Berrikuntzak ikasteko eta jolasteko eskaintza zabalagoa ekarri zuen, mugimendura mugatu gabekoa eta haurraren garapen integrala gogoan zuena (Olse, 2013; Parsons, 2011). Berrikuntza diseinatu zenean aintzat hartu ziren jolasaren dimentsio kognitiboa, dimentsio soziala zein zentzumenen ikuspegitik egindako ekarpena (Ardanaz, 2009; Garner, 2008; Parten, 1932; Piaget, 1962; Reina, 2009). Ondorioz, mugimendutik harago, jolas sinbolikoa, eraikuntzakoak edo zentzumene- 
kin lotutako esperimentazioak behatu ahal izan dira. Pentsa daiteke egoera horiek aberasgarriak izan direla haurraren ikaskuntzarako, hizkuntzaren garapenerako, garapen kognitiborako eta sozialerako (Frost et al., 2005; Rubin, 1983). Hala ere, POEMS eskalaren dimentsio honetan emaitza hobeak izateko, beharrezkoa da ikasketarako eta jolaserako interesgarriak izan daitezkeen baliabideak gordetzeko biltegi bat izatea. Biltegia izateak aukera ematen du, besteak beste, materiala berritzeko, eskaintza interesen arabera errazago moldatzeko eta erabili behar ez den uneetan materiala bera gordetzeko (DeBord et al., 2005). Ikerketa honetako ikastetxeak biltegia izan balu, asteburuetan ez zen, gertatu bezala, berrikuntzarako jarritako materialik desagertuko edo hondatuko.

Programari dagokionez, emaitza altuenak jasotako dimentsioa izan zen. Emaitza horren arrazoia da hainbat gune proposatu zirela, eta gune horietan, esan bezala, haurrak esperimentatzeko, esploratzeko edo sortzeko aukera izan zuela. Eskaintza berriak, gainera, bat egiten zuen curriculumarekin eta koherentzia zeukan barruko espazioan eskainitakoarekin. Hala ere, oraindik ere bide handia dago kanpo espazioa goi mailako baliabide pedagogikotzat hartzeko (Miranda et al., 2014). Oraindik ere 30-40 minutura mugatzen da kanpoan emandako denbora. Horrenbestez, aztertutako kanpo espazioa urrun dago Fdzilak eta Saidek (2010) garapen fisiko-psikikoan duen eraginagatik aldarrikatutako erabilera sistematikotik.

Azkenengo dimentsioari dagokionez, irakaslearen rolean ez zen aldaketarik antzeman. Irakaslearen esku-hartzeak eta komunitatearen inplikazioa berrikuntzaren aurretiko berberak izan ziren oro har. Ildo horretatik, interesgarria litzateke familien edo hezkuntza komunitatearen inplikazioa bultzatzea (Conde eta Pinzolas, 2005; Miranda et al., 2014). Zehazki irakasleari dagokionez, mugak ikusi dira haurren beharrei erantzuteko, eta, horregatik, egokia izan daiteke sentikortasun mailan eragiteko bideak jartzea (Barandiaran et al., 2015). Epe ertainerako neurri bat izan daiteke, kanpo espazioaren eskaintzatik harago, irakaslearen garapen profesionala indartzea kanpo espazioaren inguruko berariazko lanketarekin. Aukera bat izan daiteke irakaslearen jarrera eta esku-hartzeak aztertzea haurren eta irakaslearen arteko elkarrekintzak ardatz izanda (Barandiaran et al., 2015). Ildo horretatik, etorkizunari begira egokia izan daiteke, eskaintzaren berdiseinuarekin batera, irakasleak kanpo espazioan formatzeko saio bereziak prestatzea kalitatea osotasunean hobetu edo handiagotu ahal izateko, eta haurraren garapen integrala hobeto bermatzeko (Davies 1997; Barandiaran et al.,2015). Izan ere, behin kanpo espazioa diseinatuta, berebiziko garrantzia du irakasleak hartzen duen rolak espazio horri erabilera egokia emateko, diseinuak berez ez baitu bermatzen ikaste- prozesuaren kalitatea, egiten den erabilerak baizik (Barandiaran et al., 2015; Davies, 1997; Garcia, 2009; Frontela, 2013).

Kanpo espazioaren kalitatetik jolaserako jauzia egiten badugu, berrikuntza egin aurretiko eta osteko aldaketak agerian utzi behar ditugu. 
Haurrak jolas mota anitzagoetara jolastu ziren. Oreka eta gorputzaren koordinaziorako interesgarriak diren mugimenduzko jolasetik harago (Ardanaz, 2009), jolas sinbolikoak eta eraikuntza jolasak ikusi ahal izan ziren. Zehazki, rol aldaketak egin eta fantasia agerian utzi zuten, sormena eta hizkuntza sustatuta (Ardanaz, 2009; Reina, 2009). Karinek eta Wrightek (2014) proposatutako material solteekin, esperimentazioa sustatu zen eta horrekin batera, besteak beste, arreta, begi-esku koordinazioa edo memoria (Ardanaz, 2009; Reina, 2009). Era berean, Escribak (1998, 2002) defendatutako jolas sentsorialak eman ziren, adibidez musika jotzean edo usainekin esperimentatzerakoan. Ekintza horiek interesgarriak dira sormenerako, emozioetarako edo hitz berriak bereganatzeko (Ardanaz, 2009). Azkenik, gaineratu behar da proposamen guztietan haurren arteko elkarrekintzak egon zirela, eta, arestian aipa bezala, talde jolasaren egoerak areagotu zirela.

Beraz, esan daiteke eskaintza berriarekin jolasaren ezaugarriak anitzagoak izan direla. Aldi berean, Ardanazen (2009) ekarpenari men egiten badiogu, pentsa daiteke jolas anitz horiek baliagarriak izan direla garapenaren hainbat dimentsio garatzeko. Modu globalagoan hartuz gero, esan daiteke jolasa, oro har, garapena sustatzeko toki naturala dela eta berrikuntzaren osteko eskaintza jolaserako testuinguru aberatsagoa dela, kalitate irizpide gehiago betetzen dituen heinean (DeBord et al., 2010; Karin eta Wright, 2014; Larrea eta Barandiaran, 2012; Mera, 2013, Moser eta Martinsen, 2010, Parsons, 2012). Horregatik, ikerketa honen helburua ikastetxe baten kanpo espazioa haurraren garapenerako testuinguru aproposagoa izatea dela gogoratzen badugu, esan behar da berrikuntzak balio izan duela kanpo espazioaren kalitatea hobetzeko eta jolas mota anitzagoak egoteko. Arrazoi hori dela-eta, interesgarritzat hartzen da berrikuntzaren ildotik jarraitzea, horretarako aldez aurretiko egoera aztertuz eta berrikuntzak diseinatuz, aplikatuz eta ebaluatuz.

Hala ere, jakin badakigu, egindako ikerketa ikastetxe bakarreko talde batekin soilik gauzatu dela. Hortaz, ezin da hemen aipatutako emaitzarik orokortu. Horregatik, etorkizunari begira interesgarria izan daiteke era honetako berrikuntzak kanpo espazio gehiagotan diseinatzea, aplikatzea eta ebaluatzea. Era berean, ikerketa honek kanpo espazioaren eskaintzan jarri du arreta. Etorkizunari begira interesgarria litzateke irakasleekin lan egitea, beren garapen profesionalean kanpo espazioa beste modu batean ikus dezaten eta dagokion balio pedagogikoa eman diezaioten. Azkenik, etorkizunean interes handikoa izan daiteke berrikuntzaren ondorioak epe luzeago batean aztertzea, bidenabar, identifikatu ahal izateko berrikuntzarekin jarraitzeko hobekuntza posibleak. 


\begin{abstract}
The aim of this study was to conduct and validate an innovative action in an outdoor area of a preschool center. The quality of several aspects was assessed before and after carrying out the innovative action, using for that purpose the Preschool Outdoor Environment Measurement Scale. The aspects assessed were the quality of the interactions, the adequacy of the setting for playing and learning purposes, the quality of the program and the role of the teacher in charge of the space. We observed the behavior of a teacher and 26 four-year-old children in the outdoor space, in order to determine what and how they played, and what they played with. The results revealed that, following the innovative action, the quality of the outdoor space improved as regards the quality of the interactions, the adequacy of the setting for playing and learning purposes, and the quality of the program. No differences were observed in relation to the role of the teacher. As for the play activity itself, an increase in the diversity of the games played was observed following the innovative action.
\end{abstract}

Keywords: Infant education, educational innovations, outer spacel outdoor education, play, educational quality

El objetivo del presente trabajo consistió en realizar y validar una innovación en un espacio exterior de Educación infantil. Se midió la calidad de las interacciones, de la configuración para el juego y el aprendizaje, del programa y del rol del profesor en el espacio exterior con anterioridad y posterioridad a la innovación a través de Preschool Outdoor Environment Measurement Scale. A su vez, se observó a una maestra y a 26 niños y niñas de cuatro años mientras utilizaban el espacio con el objeto de identificar a qué, con qué y cómo jugaban. Los resultados obtenidos pusieron de manifiesto que, tras la innovación, la calidad del espacio exterior mejoró en las dimensiones de interacciones, configuración para el juego y el aprendizaje y el programa. Por el contrario, no se halló ninguna diferencia en la dimensión del rol de profesor. Por lo que respecta al juego, se observaron episodios de juego más diversos después de realizar la innovación.

Palabras clave: Educación infantil, innovación pedagógica, espacio exterior, juego, calidad de la educación

Le but de cette étude était de réaliser et de valider une innovation dans un espace extérieur d'éducation pour enfants. La qualité des interactions, de la configuration pour le jeu et pour l'apprentissage, du programme et du rôle de l'enseignant dans l'espace extérieur avant 
et après l'innovation ont été mesurés au moyen de Preschool Outdoor Environment Measurement Scale. De plus, nous avons procédé à l'observation d'une enseignante et de 26 garçons et filles de quatre ans pendant qu'ils utilisaient l'espace afin d'identifier à quoi, avec quoi et comment ils jouaient. Les résultats obtenus ont montré que, grâce à l'innovation, la qualité de l'espace extérieur s'est améliorée en termes d'interactions, de configuration pour le jeu ainsi que l'apprentissage et le programme. En revanche, aucune différence n'a été trouvée dans la dimension du rôle de l'enseignant. En ce qui concerne le jeu, on a remarqué des épisodes de jeu plus divers après la mise en place de l'innovation.

Mots-clé: Éducation de l'enfance, Innovation pédagogique, Jeu, Qualité de l'éducation.

\section{ERREFERENTZIAK}

Ardanaz, T. (2009). El juego en educación infantil. Innovación y experiencias educativas, 16. Hemendik jasoa: http://www.csi-csif.es/andalucia/modules/mod_ ense/revista/pdf/Numero_16/TAMARA_ARDANAZ_2.pdf

Barandiaran, A., Larrea, I., \& López de Arana, E. (2011). Haurraren ongizatea I: Oinarri psikopedagogikoak. Arrasate: Mondragon Unibertsitatea.

Barandiaran, A., Muela, A., López de Arana, E., Larrea, I., \& Martínez, A. (2015). Programa para la mejora de la sensibilidad (PMS) y habilidades de interacción del profesorado de Educación Infantil. Educatio Siglo XXI, 32, 281-302.

Bar-Haim, Y., \& Bart, O. (2006). Motor function and social participation in Kindergarten Children. Social development 15, 296-310.

Burris, K., \& Burris, L. (2011). Outdoor play and learning: Policy and Practice. International journal of Education Policy and Leadership, 6 (8). Hemendik jasoa: http://journals.sfu.ca/ijepl/index.php/ijepl/article/view/306/114

Canning, N. (2010). The influence of the outdoor environment: den-making in three different contexts. European Early Childhood Education Research Journal, 18, 555-566.

Conde, O., \& Pinzolas, J.A. (2005). Los patios de recreo: espacios para la biodiversidad. Aula de Innovación Educativa, 140, 54-57.

Coplan, R.J., Rubin, K.H., \& Findlay, L.C. (2006). Social and nonsocial play. In D.P. Fromberg, eta D. Bergen (Eds), Play from birth to twelve: Contexts, perspectives and meanings (pp. 75-86). New York: Garland Press.

Davies, M. (1997). Teacher`s role in outdoor play: Preschool teacher`s beliefs and practices. Journal of Australian research in Early childhood education, 1, 1020.

Debord, K., Hestenes, L. L., Moore, R. C., Cosco, N. G., \& McGinnis, J.R. (2005). Preschool Outdoor Environment Measurement Scale. Lewisville, NC: Kaplan Early Learning. 
Doucette, C., Kowalski, D., \& Ransom, P. (2007). Last Child in the Woods? Treating Nature-Deficit Disorder at a High School Winter Camp. Green teacher, $80,15-22$.

Early Head Start National Resource Center (2013). Supporting outdoor play and exploration for infants and toddlers. Washington: Early Head Start National Resource Center.

Ernst, J. (2014). Early childhood educators' use of natural outdoor settings as learning environments: An exploratory study of beliefs, practices, and barriers. Environmental Education Research, 20(6), 735-752.

Escriba, A. (1998). Los juegos sensoriales y psicomotores en Educación Física. Madrid: Gymnos.

Escriba, A. (2002). La utilización del juego sensorial en el ámbito educativo. Revista iberoamericana de Psicomotricidad y técnicas corporales, 6, 13-22.

Fdzila, N., \& Said, I. (2010). The trends and influential facotir of children's use of outdoor environments: A review. Procedia-Social and Behavioral Sciences, 38, 204-212.

Fjortoft, I. (2001). The natural environment as a playground for children: The impact of outdoor play activities in pre-primary school children. Early Childhood Education Journal, 29(2), 111-118.

Fjortoft, I. (2004). Landscape as playscape: the effects of natural environments on children's play and motor development. Children, Youth and Environments, 14(2), 21-44.

Frontela, B. (2013). El docente en educación infantil. Valladolid: Universidad de Valladolid.

Frost, J., Worthamn, S., \& Reifel, S. (2005). Play and child development. Columbus, OH: Merril Prentice-Hall.

Garcia, B. (2009). Las dimensiones afectivas de la docencia. Revista digital universitaria, 11, 3-14.

Garner, B.K. (2008). When students seem stalled: The missing link for too many kids who don't «get it?» cognitive structures. Educational Leadership 65(6), 32-38.

Gordillo, R. (2012). La escuela que queremos: el germen de la transformación de nuestro patio. Investigación en la escuela. 77, 43-49.

Gray, C. Gibbons, R., Bienenstock, A., Brussoni, M., Chabot, G., Herrington, S., Janssen, I., Pickett, W., Power, M., Stanger, N., Sampson, M., \& Tremblay, M.S. (2015). What Is the Relationship between Outdoor Time and Physical Activity, Sedentary Behaviour, and Physical Fitness in Children? A Systematic Review. International Journal of Environmental Research and Public Health, 12, 6455-6474.

Hestenes, L., DeBord, K., Moore, R., Cosco, N., \& McGuinnis, J. (2005). Preschool Outdoor Environment Measurement Scale (POEMS). Winston Salem: Kaplan Company.

Karin, H eta Wright ,P. (2014). «Quality outdoor play spaces for young children». Young children, 2, 3-9.

Kos, M., \& Jerman, J. (2013). Provisions for outdoor play and learning in Slovene preschools, Journal of Adventure Education and Outdoor Learning, 13(3), 189-205.

Larrea, I., \& Barandiaran, A. (2012). ¿Y si aprendemos en el exterior? Infancia: educar de 0 a 6 años, 134, 4-7. 
Luchs, A., \& Fikus, M. (2013). A Comparative Study of Active Play on Differently Designed Playgrounds. Journal of Adventure Education and Outdoor Learning, 13, 206-222.

Mårtensson, F., Boldemann, C., Söderström, M., Blennow, M., Englund, J.E., \& Grahn, P. (2009). Outdoor Environmental Assessment of Atten-tion Promoting Settings for preschool children: part of salutogenic concept. Health and place, $15,1149-1157$.

Maynard, T., \& Waters, J. (2007). Learning in the outdoor environment: a missed opportunity? Early years: An international Research Journal,27(3), 255-265.

Mera, C. (2013). Beneficios del juego en el desarrollo integral de la niñez. Revista Rayuela. No 8. Hemendik jasoa: http://revistarayuela.ednica.org.mx/sites/default/files/Claudia\%20Rebeca\%20Mera\%20Miranda.pdf

Miranda, M., Larrea, I., \& Muela, A. (2014). Ikastetxeetako kanpo espazioen kalitatea Haur Hezkuntzan. Tantak, 26, 59-76.

Miranda, N., Larrea, I., Muela, A., Martínez de Lagos, A., \& Barandiaran, A. (2015). Mejora del espacio exterior escolar desde la participación comunitaria. Participación Educativa, Segunda Época 4 (7), 161-168.

Moser, T., \& Martinsen, M.T. (2010). The outdoor environment in Norwegian kindergartens as pedagogical space for toddlers' play, learning and development. European Early Childhood Education Research Journal, 18, 457-471.

Olse, H. (2013). Creating and Enriching quality and safe outdoor environments. Dimensions of Early Childhood, 41 (3), 11-17.

Parsons, A. (2011). Young children and nature: Outdoor play and development, experiences fostering environmental consciousness, and the implications on playground design. Hemendik jasoa: https://theses.lib.vt.edu/theses/available/ etd-05062011-114155/unrestricted/Parsons_AE_T_2011.pdf

Parten, M. B.(1932). Social participation among pre-school children. Journal of Abnormal and Social Psychology, 27, 243-269

Pérez, C. (2012). La importancia del juego y los juguetes para el desarrollo integral de los niños/as de educación infantil. Revista Autodidacta, 9 (1), 10-20.

Piaget, J. (1962). Play, dreams, and imitation in childhood. New York: Norton.

Reina, C. (2009). El juego infantil. Revista Digital Innovación y experiencias educativas, 15, 1-9. Hemendik jasoa: http://www.csi-csif.es/andalucia/modules/ mod_ense/revista/pdf/Numero_15/CRISTINA_REINA_1.pdf

Rengel, K. (2014). Preschool Teacher`s attitudes towards play. Croatian Journal of Education, 16, 113-125.

Rubin, K.H., Fein, G., \& Vandenberg, B. (1983). Play. In P.H. Mussen (Series Ed.) and E.M Hetherington, (Vol, Ed), Handbook of child psychology: Vol. 4: Socialization, personality and social development (pp. 693-774). New York: Wiley.

Segura, M.E. (2005) ¿Cómo propiciar en los niños afectividad y autonomía personal? Umbral, 8, 160-163.

Smilansky, S. (1968). The effects of sociodramatic play on disadvantaged children: Preschool Children. New York: Wiley.

The Institute for Outdoor Learning. (2011). What is the Outdoor Learning. Hemendik jasoa: http://www.outdoor-learning.org/

White, H. (1992). Identity and control: A Structural Theory of Social Action. Princeton, NJ: Princeton University Press. 